IJMS 16 (1), 31-55 (2009)

\title{
SIKAP, NORMA SUBJEKTIF DAN KAWALAN GELAGAT DITANGGAP TERHADAP NIAT GELAGAT KEPATUHAN ZAKAT PENDAPATAN GAJI
}

\author{
ZAINOL BIDIN \\ KAMIL MD. IDRIS \\ College of Business \\ Universiti Utara Malaysia
}

\begin{abstract}
ABSTRAK
Sorotan kajian berkaitan zakat menyentuh soal bagaimana pelbagai faktor mempengaruhi kepatuhan zakat ke atas pendapatan penggajian. Namun begitu, faktor niat tidak dibicarakan dalam model gelagat kepatuhan zakat gaji sebelum ini, sedangkan niat adalah elemen yang terdekat sekali dalam menentukan gelagat seseorang. Bagaimanapun, faktor niat tidak boleh berlaku secara tersendiri kerana ada beberapa faktor lain pula yang berkait rapat dengan ketentuan niat. Justeru, kajian ini dijalankan bagi mengenal pasti faktor penentu niat gelagat kepatuhan zakat gaji dalam kalangan anggota masyarakat Islam di negeri Kedah. Teori Gelagat Terancang (Theory of Planned Behavior) yang dibangunkan oleh Ajzen (1985) digunakan sebagai landasan kepada kajian ini. Meskipun demikian, kajian ini menggunakan pendekatan yang berbeza daripada kebiasaannya, iaitu menghuraikan faktor sikap dan faktor norma subjektif dalam teori berkenaan kepada dimensi yang lebih khusus bagi mendapat kefahaman yang lebih jelas dan komprehensif. Hasil kajian menunjukkan bahawa sikap dan norma subjektif masing-masing dapat dileraikan kepada enam dan tiga komponen. Kesemua komponen tersebut apabila diuji dalam model regresi berganda menghasilkan dapatan yang lebih jelas. Tiga komponen sikap, tiga komponen norma subjektif, dan kawalan gelagat ditanggap berhubungan secara positif dan signifikan ke atas niat gelagat kepatuhan. Justeru, kajian ini menyokong bahawa sikap dan norma subjektif terhadap niat gelagat kepatuhan zakat gaji adalah terdiri daripada pelbagai dimensi dan lebih jelas dikaji dengan menggunakan setiap dimensi tersebut sebagai angkubah berasingan. Justeru, pihak berkuasa zakat disarankan membuat dan melaksanakan suatu pelan tindakan yang memfokus kepada bentuk sikap, kumpulan rujukan serta faktor kawalan gelagat ditanggap.
\end{abstract}

Kata kunci: Sikap; norma subjektif; kawalan gelagat ditanggap; niat; zakat. 


\begin{abstract}
Purpose - Previous zakah literatures have shown that many factors may influence the compliance behaviour of zakah on employment income. However, variable intention has not been taken as the focal point previously, although intention is said to be the immediate antecedent variable to one's compliance behaviour. Thus, this study was conducted to determine factors that influence the variable intention to comply, with zakah payment among Muslim employees. Theory of planned behaviour, which was developed by Ajzen (1985), was applied as a basis for this study. This study used a different approach than the usual one by decomposing the main factors (i.e. attitude and subjective norm) into several dimensions. Meanwhile, perceived behavioural control does not use this approach.
\end{abstract}

Design/Methodology/Approach - This study is based on an extensive literature review and data were generated from a sample $250 \mathrm{Muslim}$ individuals. A multiple regression analysis was used for statistical analysis.

Findings - The results showed that attitude and subjective norm can be decomposed into six and three components, respectively. Better results were found when all the decomposed components were tested in multiple regression analysis. Three components of attitude, three components of subjective norm, and perceived behavioural control were found to be significantly related to the intention to comply with zakah payment.

Originality/Value - This study supports the contention that attitude and subjective norm in the model of zakat intention of compliance behaviour are respectively composed of several dimensions and provide good results if each dimension is treated as a separate variable.

Keywords - Attitude; subjective norm; perceived behavioural control;intention; zakat.

Paper type - Research Paper.

\title{
PENGENALAN
}

Sumber pendapatan zakat tidak dapat dinafikan kepentingannya kepada negara. Umumnya, agihan pendapatan zakat dapat menjana dan merancakkan kuasa beli masyarakat sekaligus meningkatkan produktiviti negara. Malah, zakat juga dapat menjamin kestabilan 
ekonomi dan boleh menyelesaikan sebahagian daripada masalah pembangunan negara. Seperti yang disarankan oleh mantan Perdana Menteri Datuk Seri Abdullah Ahmad Badawi, iaitu zakat merupakan satu instrumen yang penting dalam membangunkan ekonomi ummah termasuk menghapuskan sebahagian daripada masalah kemiskinan (Utusan Malaysia, 2006). Pembangunan negara dan ummah dapat dilaksanakan dengan lebih baik sekiranya sumber dana zakat dapat dipertingkatkan. Sumber dana zakat datangnya daripada pelbagai punca seperti zakat pendapatan gaji, wang simpanan, perniagaan, ternakan, saham, emas, padi dan sebagainya.

Zakat pendapatan gaji masih menjadi isu di negara kita. Pendapatan zakat jenis ini menghadapi masalah kutipan yang rendah dalam kalangan pekerja Muslim yang layak walaupun fatwa wajib zakat gaji telah lama dikeluarkan (Kamil, 2002). Umpamanya, negeri Kedah telah mewartakan wajib zakat gaji pada 19 April, 1986 dengan menggunakan seksyen 38(2) Undang-Undang Pentadbiran Islam Kedah 1962 dalam Warta Kerajaan No. 146 (Mujaini Tarimin, 1995). Negeri Perlis telah memfatwakan zakat pendapatan gaji wajib pada 20 Oktober 1991 (Jawatankuasa Syariah Negeri Perlis, 1996). Sementara itu, Jawatankuasa Perunding Hukum Syarak (Fatwa) Negeri Selangor telah memutuskan wajib membayar zakat gaji dan telah diwartakan pada 16 Oktober 2001 di bawah Enakmen Pentadbiran Perundangan Islam, 1989, pindaan 2003 seksyen 49 (i) dan (ii).

Walaupun fatwa wajib zakat ke atas pendapatan gaji telah lama dikeluarkan, namun masih ramai individu Muslim tidak membayar zakat atau tidak patuh kepada fatwa wajib zakat gaji ini. Fakta ini disokong oleh beberapa kajian dan juga laporan daripada pelbagai sumber. Umpamanya, kajian gelagat kepatuhan zakat gaji Kamil (2002) ke atas pekerja Muslim yang bekerja dengan kerajaan persekutuan di negeri Kedah mendapati bahawa hanya sekitar 35\% daripada 353 responden yang layak menunaikan zakat gaji. Dalam kajian lain negeri Perlis menunjukkan aras kepatuhan yang rendah (Kamil, Chek Derashid, \& Engku Ismail, 1997) iaitu hanya 35\% sahaja yang membayar zakat gaji. Di Pulau Pinang pula bilangan pekerja Muslim yang membayar zakat gaji hanyalah sekitar 39\% iaitu 18,552 daripada 50,000 orang yang layak mengeluarkan zakat gaji ("50,000 pekerja", 2000).

Fenomena gelagat kepatuhan yang rendah dalam kalangan pekerja Muslim ini boleh di atasi jika pengurusan terhadap punca berlakunya 
ketidakpatuhan dapat ditangani. Menurut Ajzen dan Fishbein (1980), punca utama kepada sesuatu gelagat ialah niat. Niat pula tercetus apabila tiga faktor utama iaitu sikap terhadap gelagat (attitude towards behavior), norma subjektif (subjective norm), dan kawalan gelagat ditanggap (perceived behavioral control) memainkan peranan (Ajzen, 1991). Niat merupakan fokus bagi kajian ini memandangkan kebanyakan kajian sebelum ini mengenai zakat jarang menumpukan niat sebagai agen yang boleh mempengaruhi gelagat kepatuhan zakat. Malah dalam hadis juga menegaskan kepentingan niat dalam melakukan sesuatu perbuatan. Umpamanya, sebuah hadis Rasulullah SAW yang bermaksud bahawa "amal perbuatan seseorang itu tergantung pada niatnya dan bagi seseorang apa yang ia niatkan" (Mohd Yusof Abas, 1981). Walaupun Zainol dan Kamil (2007) menjalankan kajian tentang niat gelagat kepatuhan zakat, namun kajian mereka tidak berlandaskan teori gelagat terancang di mana elemen kawalan gelagat ditanggap yang berperanan penting tidak diambil kira. Justeru, berlaku kelompangan dalam teori yang menjelaskan gelagat kepatuhan zakat pendapatan gaji.

Kajian ini bertujuan untuk mendalami kefahaman tentang sikap, norma subjektif, dan kawalan gelagat ditanggap terhadap niat gelagat kepatuhan zakat gaji dengan mengaplikasikan teori gelagat terancang. Sehubungan itu, dua soalan berikut diajukan: a) adakah konstruk sikap, norma subjektif dan kawalan gelagat ditanggap berhubungan dengan niat gelagat kepatuhan zakat gaji? b) bagaimanakah kekuatan hubungan di antara norma-norma subjektif, sikap, dan kawalan gelagat ditanggap terhadap niat gelagat kepatuhan zakat pendapatan gaji? Berdasarkan soalan-soalan kajian di atas, maka objektif berikut perlulah dicapai: a) mengenal pasti hubungan konstruk sikap, norma subjektif dan kawalan gelagat ditanggap dengan niat gelagat kepatuhan zakat gaji.; b) menentukan kekuatan hubungan di antara sikap, norma subjektif, dan kawalan gelagat ditanggap terhadap niat gelagat kepatuhan zakat pendapatan gaji.

Ketidakpastian dalam membuat keputusan dan melaksanakan usaha bagi meningkatkan pertumbuhan kutipan zakat dalam kalangan institusi zakat pada masa sekarang adalah disebabkan oleh pelbagai faktor. Antaranya adalah ketiadaan garis panduan yang menyeluruh bagi mengenal pasti faktor-faktor yang berkaitan dengan prestasi institusi berkenaan. Umpamanya, maklumat mengenai niat gelagat anggota masyarakat Muslim terhadap zakat penggajian perlulah diketahui supaya beberapa langkah yang sewajarnya dapat diperbaiki jika tahap pencapaiannya rendah. Secara teorinya kutipan zakat gaji 
adalah rendah sekiranya niat gelagat anggota masyarakat terhadap zakat penggajian juga rendah. Malah niat gelagat pembayar zakat patut diberi perhatian oleh pihak institusi zakat kerana ianya merupakan titiktolak kepada sesuatu perbuatan. Memahami faktor-faktor penentu bagi niat gelagat kepatuhan akan membantu pihak berkuasa zakat lebih bersedia dalam menyesuaikannya melalui perancangan dan peramalan pada masa hadapan.

Kajian ini cuba menambahbaik model awal niat gelagat kepatuhan zakat pendapatan gaji dengan memperkenalkan pemboleh ubah kawalan gelagat ditanggap sebagai salah satu pemboleh ubah utama. Setakat ini belum ada kajian seperti ini dijalankan khusus bagi institusi zakat yang bukan sahaja dipengaruh oleh faktor dalaman tetapi juga faktor luaran. Dengan demikian, kajian ini diharap dapat memberi sumbangan kepada pihak berkuasa zakat bagi membantu mereka membangunkan lebih efektif lagi dari segi program-program pemasaran yang boleh meningkatkan niat gelagat kepatuhan terhadap zakat gaji.

\section{SOROTAN LITERATUR}

\section{Teori Gelagat Terancang}

Teori gelagat terancang (Ajzen, 1991) adalah suatu model teoretikal psikologi sosial yang popular dan sering diaplikasikan dalam menerangkan pelbagai situasi gelagat. Teori gelagat terancang merupakan kesinambungan daripada teori tindakan beralasan (theory of reasoned action) yang mana satu tambahan konstruk kawalan gelagat ditanggap muatkan di dalammnya. Ini bertujuan bagi menangani situasi yang mana individu tidak mempunyai kawalan sepenuhnya (incomplete voltional control) terhadap sesuatu gelagat. Teori ini menegaskan bahawa niat untuk melaksanakan sesuatu gelagat adalah dipengaruh oleh sikap terhadap gelagat, norma-norma subjektif, dan kawalan gelagat ditanggap. Bagaimanapun, dalam bidang zakat, literatur tentang teori ini sukar ditemui. Sebagai suatu model yang umum, adalah munasabah bagi menjangkakan model ini boleh menerangkan gelagat kepatuhan zakat. Bagi tujuan kajian ini, niat gelagat individu Muslim terhadap pembayaran zakat gaji adalah ditentukan oleh tiga faktor utama iaitu sikap terhadap gelagat; norma-norma subjektif dan kawalan gelagat ditanggap. Teori gelagat terancang ini direka bagi meramal dan menerangkan gelagat manusia dalam gelagat yang spesifik (Ajzen, 1991). Teori ini mencadangkan bahawa penentu paling hampir kepada gelagat ialah niat gelagat. 
Kajian mengenai niat gelagat sukar ditemui dalam bidang zakat. Malah kajian dalam bidang yang serupa dengan zakat, seperti pematuhan cukai, juga sangat terhad. Bagaimanapun, gelagat sosial dalam bidang lain seperti kesihatan, penggunaan sistem maklumat, pendidikan dan sebagainya banyak dilaporkan dalam pelbagai artikel atau jurnal. Niat gelagat telah diiktiraf sebagai perantaraan (mediator) yang penting dalam hubungan antara gelagat dan faktor-faktor lain seperti sikap terhadap gelagat, norma-norma subjektif dan persepsi kawalan gelagat (Ajzen \& Fishbein, 1980; Ajzen, 1991). Niat gelagat merujuk kepada keinginan seseorang untuk melaksanakan sesuatu gelagat dan ianya merupakan antesiden (antecedent) sebelum berlakunya gelagat. Bagi memahami sesuatu gelagat, adalah penting bagi mengenal pasti faktor-faktor penentu niat (Hanno \& Violette, 1996). Oleh kerana niat memainkan peranan yang penting dalam menentukan gelagat seseorang, maka seharusnya kita mendapatkan penjelasan bagaimana niat terhadap kepatuhan zakat boleh tercetus. Justeru, kajian ini akan cuba mengadaptasikan teori gelagat terancang iaitu satu teori yang meletakkan keutamaan niat sebagai pencetus kepada gelagat.

\section{Sikap}

Banyak perbincangan dalam literatur menyentuh bahawa sikap memainkan peranan utama dalam mempengaruhi gelagat kepatuhan. Ini kerana sebarang usaha bagi meningkatkan gelagat kepatuhan, elemen sikap perlu diperbaiki terlebih dahulu (Silver, 1995). Begitu juga dalam teori gelagat terancang, sikap merupakan salah satu angkubah yang utama bagi menjangkakan gelagat seseorang (Ajzen, 1991). Umumnya, literatur psikologi banyak membicarakan sikap sebagai terdiri daripada tiga komponen yang utama iaitu komponen kognitif (cognitive); afektif (affective); dan gelagat (behavioral). Komponen kognitif merupakan idea dan kepercayaan yang dipegang oleh seseorang terhadap sesuatu objek sikap. Komponen kedua iaitu afektif berkait dengan perasaan dan emosi ke atas sesuatu objek. Komponen ketiga pula adalah gelagat yang merupakan kecenderungan kepada gelagat.

Pelbagai kaedah telah digunakan dalam mengkaji komponen sikap (Oskamp, 1991). Sikap terhadap gelagat seperti yang didefinisikan oleh Ajzen (1991) merupakan darjah di mana seseorang individu yang mempunyai penilaian baik atau tidak baik ke atas sesuatu gelagat. Namun begitu, ianya tidak memasuki elemen tingkah laku seperti yang dibincangkan oleh para pengkaji sikap yang terdahulu seperti Alport (dalam nukilan Aronson \& Pratkanis) dan Sheriff dan Hovland (1961). Sherif dan Hovland (1961) memperkenalkan teori sikap dan 
pengukurannya berpandukan konsep 'attitude latitude' di mana seseorang individu mungkin menerima atau menolak tentang sesuatu isu. Menurut Sherif dan Hovland (1961) proses seseorang membuat pertimbangan terhadap sesuatu objek sosial seperti kumpulan orang, peristiwa, benda, isu dan sebagainya perlulah memasuki elemen kognitif dan afektif secara serentak. Ini kerana konsep ini menekankan komponen kognitif dan afektif adalah saling bertaut (inextricably intertwined) dan sukar dileraikan.

Banyak kajian menyokong bahawa sikap terdiri daripada pelbagai dimensi. Umpamanya, Taylor dan Todd (1995) mendapati bahawa bagi memahami hubungan antara struktur kepercayaan dan angkubah penyumbang kepada niat, maka penguraian kepercayaan yang berkaitan dengan sikap perlu dilakukan. Shimp dan Kavas (1984) menghujah bahawa komponen kognitif sikap tidak boleh dilakukan dengan hanya menggunakan satu konsep sahaja. Rhodes dan Courneya (2003) menguraikan konsep sikap kepada afektif (seperti gembira/ tidak gembira) dan instrumen (memberi faedah/merosakkan). Dapatan daripada kajian itu menunjukkan kedua-dua komponen afektif dan instrumen terhadap niat adalah optima dan signifikan jika lain-lain konsep dikawal. Dapatan daripada Ajzen dan Driver (1992) juga menyokong pengasingan komponen sikap kepada afektif dan instrumen. Lau (2002) menguraikan komponen sikap kepada lima konsep iaitu tanggapan kebergunaan (perceived usefulness), tanggapan senang diguna (perceived ease of use), faedah yang berkaitan, kesesuaian dan keboleh perhatian (observability). Kelima-lima konsep tersebut adalah berkolerasi dengan sikap. Dalam kajian laluan melintang (crossover path) yang dilakukan oleh Shimp dan Kavas (1984), komponen sikap dapat diuraikan kepada tiga subset iaitu menyulitkan (inconvenience), bebanan (encumbrances), dan ganjaran (rewards). Dalam bidang pencukaian, Bobek (1997) menggunakan lima skel pengukuran sikap (kepercayaan cukai dibayar, kepercayaan tidak sah, kepercayaan bersalah, kepercayaan penalti, dan kepercayaan kesaksamaan) mendapati kelima-lima skel tersebut mempunyai hubungan yang signifikan terhadap sikap. Dalam bidang berkaitan dengan zakat pula, analisis faktor ke atas sikap individu Muslim terhadap gelagat kepatuhan zakat gaji mendapati ianya dapat dipecahkan kepada lima dimensi (Kamil, 2002), iaitu Sikap Penerimaan Am, Sikap Penerimaan Positif, Sikap Penerimaan Waswas, Sikap Penerimaan Bersyarat, dan Sikap Penerimaan Teknikal.

Ajzen (1991) mendefinisikan sikap merupakan penilaian baik atau tidak baik terhadap sesuatu gelagat. Bagaimanapun, seperti yang dibuat oleh 
penyelidik terdahulu, sikap merupakan suatu konstruk yang kompleks dan perlu dirungkaikan kepada beberapa komponen yang lebih kecil agar dapat dijelaskan dengan lebih spesifik. Oleh kerana elemen kognitif dan afektif dalam sikap saling terikat dan sukar dileraikan, adalah lebih baik sekiranya dimasukkan elemen-elemen kognitif, afektif dan tingkah laku. Sehubungan itu, sikap terhadap fatwa zakat gaji didefinisikan sebagai meliputi perasaan menyokong atau menentang, penilaian, suka atau benci, atau perasaan positif atau negatif terhadap zakat gaji. Walaupun Kamil (2002) berjaya membuktikan sikap terdiri daripada beberapa komponen yang lebih kecil, namun kajian beliau tidak berlandaskan teori gelagat terancang. Model gelagat kepatuhan zakat pendapatan gaji yang diperkenalkan beliau tidak mengambil kira sejauh manakah niat gelagat kepatuhan zakat gaji yang merupakan pokok dalam teori ini. Tambahan lagi, tumpuan kajian beliau hanya dalam kalangan pekerja Muslim kakitangan kerajaan persekutuan sahaja. Justeru, bagi mendapatkan penjelasan yang lebih menyeluruh, kajian ini akan menumpukan niat gelagat sebagai faktor yang berperanan dalam gelagat kepatuhan zakat gaji seperti yang dicadangkan oleh teori gelagat terancang.

\section{Norma Subjektif}

Selain sikap, norma-norma subjektif juga memainkan peranan dalam mempengaruhi gelagat kepatuhan. Walaupun norma subjektif merupakan salah satu unsur utama dalam teori gelagat terancang, namun pemboleh ubah ini didorong oleh teori pembelajaran sosial. Teori pembelajaran sosial menfokuskan pengaruh persekitaran keatasindividu (Bandura, 1977). Teori ini menekankan bahawa gelagat merupakan satu keputusan daripada interaksi di antara kedua-dua faktor personal dan persekitaran. Faktor utama yang menentukan kepatuhan datangnya daripada pendapat rakan sebaya (peer) dan lain-lain pengaruh sosial yang berkaitan. Umpamanya, faktor rakan sebaya boleh mempengaruhi individu sama ada berbentuk ganjaran mahupun hukuman. Teori ini merujuk kepada bagaimana individu belajar berkenaan gelagat sosial melalui pemerhatian ke atas orang lain dan meniru mereka (Bandura, 1977). Holloway dan Watson, (2002) menyatakan bahawa gelagat dibentuk melalui pembelajaran ke atas situasi persekitaran. Gelagat juga bukan hanya ditentukan melalui pengalaman malah juga melalui pemerhatian yang berdasarkan norma-norma yang dipegang oleh masyarakat. Norma-norma ini berpandukan kepada kepercayaan yang dipegang oleh sesetengah masyarakat sebagai sesuatu yang betul, boleh diterima dan dibenarkan (Aronson, Wilson, \& Akert, 1999). 
Kajian mendapati konsep norma subjektif ini boleh diuraikan kepada beberapa komponen yang lebih khusus. Beberapa kajian sebelum ini mencadangkan pendekatan bagi menghuraikan struktur kepercayaan normatif kepada kumpulan rujukan yang relevan (Oliver \& Bearden, 1985; Shimp \& Kavas, 1984). Penguraian perlu dilakukan disebabkan pandangan di antara kumpulan rujukan tersebut berbeza-beza. Misalnya, dari segi pandangan penggunaan teknologi maklumat, seseorang rakan sebaya (peer) mungkin tidak suka dalam hal penggunaan sesuatu sistem tertentu kerana berpendapat ianya mengakibatkan banyak perubahan dalam kerja hariannya. Tetapi pada masa yang sama pihak atasan (superior) pula berpendapat bahawa penggunaan teknologi maklumat tersebut dapat meningkatkan produktiviti. Dalam situasi begini, satu unit struktur normatif mungkin tidak menunjukkan pengaruh ke atas norma subjektif atau niat kerana kesan kumpulan tidak dilibatkan secara komprehensif. Chu dan $\mathrm{Wu}$ (2004) menguraikan kumpulan rujukan kepada dua kumpulan kepercayaan normatif prima (primary normative belief) iaitu keluarga dan rakan-rakan dan kepercayaan normatif sekunder (sekunder normative belief) seperti penyelia dan rakan sebaya. Mereka mendapati kepercayaan normatif sekunder berhubungan secara signifikan dengan norma-norma subjektif. Norma-norma subjektif tersebut kemudiannya berhubungan secara positif dengan niat gelagat. Taylor dan Todd (1995) melaporkan bahawa kumpulan rujukan seperti rakan sebaya dan pihak atasan mempengaruhi norma-norma subjektif dengan signifikan. Begitu juga Rhodes dan Courneya (2003) mendapati kawan-kawan, ahli keluarga, dan pekerja merupakan komponen yang signifikan ke atas tekanan sosial (norma subjektif). Berdasarkan perbincangan ini, adalah wajar kajian ini melihat konsep norma subjektif dari pelbagai kumpulan rujukan dalam mempengaruhi niat gelagat kepatuhan zakat.

\section{Kawalan Gelagat Ditanggap}

Menurut teori gelagat terancang, kawalan gelagat ditanggap merujuk kepada darjah kawalan seseorang individu ke atas sesuatu gelagat yang akan dilakukan. Kawalan gelagat ditanggap memainkan peranan yang penting dalam teori gelagat terancang. Pemboleh ubah kawalan gelagat ditanggap mencerminkan persepsi individu ke atas kekangan dalaman dan luaran ke atas sesuatu gelagat (Ajzen, 1991). Di samping itu, ianya berperanan sebagai kepercayaan kawalan (control belief) di mana seseorang individu tidak mempunyai sepenuhnya faktor kawalan (control factor) iaitu faktor-faktor kawalan dalaman dan luaran ke atas gelagat. Faktor kawalan dalaman meliputi kemahiran, keupayaan, 
maklumat, sumber, dan emosi seperti tekanan dan sebagainya. Faktor kawalan luaran pula datangnya daripada persekitaran. Kawalan gelagat ditanggap ini akan berhubungan dengan gelagat apabila adanya penerimaan di antara persepsi kawalan (perceived control) dan kawalan sebenar individu ke atas gelagat tersebut. Seseorang individu mungkin kuat niatnya untuk melaksanakan gelagat tetapi masih tidak melaksanakannya kerana disebabkan kurangnya keupayaan, kekangan luaran atau lain-lain angkubah (Trafimow, Sheeran, Conner \& Finlay, 2002). Khususnya, kepercayaan kawalan merupakan asas penentu kepada kawalan gelagat ditanggap iaitu merujuk kepada kepercayaan seseorang individu berkaitan dengan sumber-sumber atau peluangpeluang yang ada termasuk juga halangan untuk melakukan sesuatu gelagat (Bobek \& Hatfield, 2003). Jika seseorang ingin melakukan sesuatu gelagat tetapi dihadkan dengan kawalan kemahuannya, maka kawalan gelagat ditanggap menjadi salah satu faktor penting ke atas niat untuk melaksanakan gelagat tersebut.

Para penyelidik sebelum ini (Elliott, Armitage \& Baughan, 2003; Fang \& Shih, 2004; Ingram, Cope, Harju, \& Wuensch, 2000) melaporkan kawalan gelagat ditanggap berhubungan secara signifikan dengan niat gelagat. Sekiranya kawalan kemahuan adalah tidak sepenuhnya, dan jika ditambah angkubah kawalan gelagat ditanggap, maka ianya dapat meramalkan niat dengan signifikan (Ajzen \& Madden, 1986). Dalam bidang pencukaian, Bobek dan Hatfield (2003) melaporkan bahawa kawalan gelagat ditanggap mempunyai hubungan yang positif terhadap niat kepatuhan cukai. Ajzen dan Driver (1992) mendapati kawalan gelagat ditanggap meningkatkan ramalan ke atas niat untuk melakukan aktiviti-aktiviti rekreasi dimasa lapang. Analisis meta (meta-analysis) yang dilakukan oleh Notani (1998) ke atas teori gelagat terancang melaporkan bahawa sejumlah 51 ujian hubungan antara kawalan gelagat ditanggap dengan niat gelagat mendapati sebanyak $42(82.4 \%)$ ujian adalah berhubungan secara signifikan. Sementara itu, daripada 35 ujian ke atas hubungan kawalan gelagat ditanggap dengan gelagat hanya 17 (48.6\%) ujian berhubungan secara signifikan. Dengan lain perkataan, rangka kerja teori gelagat terancang dibangunkan dengan menfokuskan konstruk kawalan gelagat ditanggap sebagai satu peramal ke atas niat dan gelagat sebenarnya. Sehubungan itu, dalam konteks bayaran zakat adalah dijangkakan dapat menjelaskan bahawa individu yang mempunyai kawalan gelagat ditanggap tinggi sepatutnya mempunyai niat yang tinggi untuk membayar zakat daripada mereka yang rendah kawalan gelagat ditanggapnya. Justeru, rangka kerja kajian niat gelagat kepatuhan zakat gaji digambarkan seperti dalam Rajah 1. 


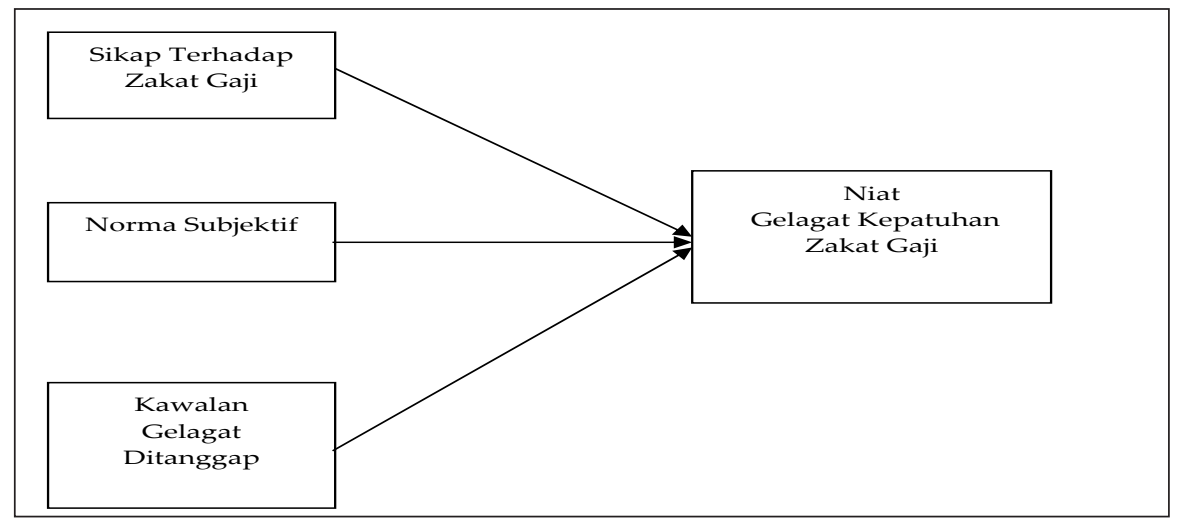

Rajah 1: Kerangka teori niat gelagat kepatuhan zakat (berasaskan Teori Gelagat Terancang)

Berdasarkan perbincangan ini, hipotesis seperti berikut dicadangkan bagi kajian ini:

$\mathrm{H}_{1} \quad$ Sikap $_{\mathrm{i-k}}$ terhadap zakat pendapatan gaji mempunyai hubungan positif dengan niat gelagat kepatuhan zakat gaji.

$\mathrm{H}_{2} \quad$ Norma subjektif ${ }_{\mathrm{i}-\mathrm{k}}$ mempunyai hubungan positif dengan niat gelagat kepatuhan zakat gaji.

$\mathrm{H}_{3} \quad$ Kawalan gelagat ditanggap mempunyai hubungan positif dengan niat gelagat kepatuhan zakat gaji.

di mana:

$\mathrm{i}-\mathrm{k}=$ adalah komponen-komponen bagi sikap dan norma subjektif

\section{METODOLOGI KAJIAN}

\section{Kutipan Data dan Persampelan}

Unit analisis dalam kajian ini terdiri daripada pekerja Muslim yang berkhidmat di organisasi sektor kerajaan dan swasta serta tertakluk kepada potongan cukai berjadual (PCB). Negeri Kedah dipilih sebagai lokasi kajian memandangkan ia adalah salah sebuah negeri yang telah lama memfatwakan pendapatan gaji sebagai wajib serta telah mewartakannya sejak 1986 (Kamil, 2002), iaitu melebihi 20 tahun. 
Rangka persampelan kajian terdiri daripada individu yang tertakluk kepada potongan cukai berjadual (PCB) seperti yang terdapat dalam daftar PCB di Lembaga Hasil Dalam Negeri cawangan Kedah. Individu yang terdapat dalam senarai tersebut merupakan individu pembayar cukai yang layak dikenakan zakat gaji kerana had pendapatan minimum yang dikenakan cukai adalah dalam anggaran RM30,000 sedangkan had pendapatan minimum zakat (Nisab) adalah sekitar RM4,464. Terdapat 40,000 orang dalam senarai tersebut pada 31 Disember 2005. Bagi tujuan pensampelan kaedah multistage cluster diamalkan.

Kaedah multistage cluster bermula dengan mengenal pasti dan menyenarai semua organisasi di negeri Kedah yang mempunyai bilangan pekerja yang tertakluk kepada PCB melebihi 20 orang. Persampelan rawak dilaksanakan ke atas senarai organisasi berkenaan. Sebanyak 30 organisasi (awam dan swasta) dipilih dan organisasi yang terpilih akan dituju dan diedarkan soal selidik. Bilangan responden yang diperlukan bagi setiap organisasi ialah 20 orang. Ini menjadikan saiz sampel kepada 600 orang (20 orang x 30 organisasi). Sebanyak 296 berjaya dikutip dan 250 daripadanya boleh digunakan bagi tujuan analisis. Bilangan ini mewakili sebanyak $42 \%$ kadar pulangan sampel yang boleh digunakan bagi tujuan analisis. Saiz sampel yang sesuai bagi membolehkan penyeluruhan (generalization) adalah pada tahap di antara 15 hingga 20 bagi setiap pemboleh ubah bebas (Hair, Anderson, Tatham \& Black, 1998). Bagi tujuan analisis faktor dan regresi, bilangan saiz sampel yang sesuai adalah melebihi 20 kali ganda pemboleh ubah bebas (Coake \& Steed, 1999).

\section{Teknik Analisis}

Bagi setiap angkubah yang berbentuk konstruk diuji dengan analisis kebolehpercayaan (reliability) dengan mengikut kaedah konsistensi dalaman iaitu kaedah yang menentukan darjah korelasi di antara item-item yang mengukur konsep yang sama. Ukuran yang selalu digunakan bagi menilai tahap kebolehpercayaan ini adalah koefisien alpha (Churchill, 1979; Nunnaly, 1978). Umumnya, koefisien alpha atau Crobanch Alpha yang berada di antara 0.70 hingga 0.90 adalah dianggap mencukupi dan 0.55 hingga 0.70 dianggap sederhana bagi konstruk yang luas (Nunnally, 1978). Nilai alpha yang diperolehi bagi semua konstruk dalam kajian ini melebihi 0.70 dan mencukupi. 
Analisis faktor diaplikasikan bagi tujuan merungkaikan ketiga-tiga konstruk tersebut dengan berpandukan analisis komponen prinsipal (principle component analysis) dengan putaran varimax. Analisis faktor diaplikasikan bagi meneroka dan mengenal pasti sebilangan kecil faktor yang tersirat daripada sekumpulan besar angkubah bebas. Faktor yang kecil ini kemudiannya digunakan sebagai input kepada analisis regresi. Nilai eigenvalues yang melebihi 1.0 bagi setiap faktor dianggap signifikan (Hair et al., 1998). Pemeriksaan ke atas matriks data dilakukan dahulu sebelum analisis faktor dibuat. Ini bagi memastikan ianya mempunyai korelasi yang mencukupi untuk memberi justifikasi tentang kesesuaian penggunaan analisis faktor (Churchill, 1979).

Ukuran Kaiser-Meyer-Olkin (KMO) dan Bartlett Test of Sphericity digunakan bagi tujuan tersebut. KMO adalah ukuran kecukupan sampel (measure of sampling adequacy) di mana nilai KMO yang kecil menunjukkan bahawa angkubah tidak boleh diramalkan atau dijelaskan oleh angkubah lain tanpa ralat yang signifikan (Hair et al.,1988). Nilai KMO dalam lingkungan 0.90 dianggap cemerlang; 0.80 membanggakan; 0.70 lebih dari biasa; 0.60 biasa; 0.50 mendukakan; dan nilai kurang 0.50 tidak boleh diterima (Hair et al., 1988). Ujian Keseferaan Bartlett (Bartlett Test of Sphericity) pula digunakan untuk menguji sama ada matriks korelasi adalah matriks identiti yang akan memastikan bahawa model faktor ini sesuai atau tidak. Jika nilai khi kuasa dua (chi-square) besar (sig.<0.05), analisis faktor boleh diteruskan dan sebaliknya. Setiap faktor yang signifikan diteliti beban faktornya bagi setiap item yang terkandung di dalamnya. Sebarang item yang mempunyai beban faktor kurang daripada 0.4 akan digugurkan. Kemudian setiap faktor akan dikira sebagai satu pemboleh ubah berasingan dan skor faktor dijadikan input bagi analisis regresi.

Regresi berganda (multiple regression) digunakan bagi tujuan analisis kajian ini. Pemboleh ubah bebas hasil daripada analisis faktor dijadikan input dalam model regresi ini sebagai fungsi kepada niat gelagat kepatuhan zakat gaji. Model regresi berganda yang diuji adalah seperti berikut:

$$
\begin{aligned}
\text { NGK }= & \alpha+\beta_{11} C_{11}+\beta_{12} C_{12}+\beta_{13} C_{13}+\beta_{14} C_{14}+\beta_{15} C_{15}+\beta_{16} C_{16}+\beta_{21} D_{21}+\beta_{22} D_{22}+ \\
& \beta_{23} D_{23}+\beta_{31} E_{31}
\end{aligned}
$$


di mana:

$\begin{array}{ll}\text { NGK } & \text { adalah niat gelagat kepatuhan zakat gaji } \\ \beta & \text { adalah koefisien angkubah masing-masing } \\ \mathrm{C}_{11}-\mathrm{C}_{16} & \text { adalah dimensi sikap terhadap fatwa zakat gaji } \\ \mathrm{D}_{21}-\mathrm{D}_{23} & \text { adalah dimensi kumpulan rujukan } \\ \mathrm{E}_{31} & \text { adalah kawalan gelagat ditanggap }\end{array}$

\section{KEPUTUSAN}

Ujian tahap kebolehpercayaan menunjukkan ketiga-tiga angkubah tersebutmelepasi0.70iaitupanduanminimayangdisyorkanolehNunnally (1978). Nilai cronbach alpha bagi setiap angkubah yang terlibat adalah niat gelagat kepatuhan zakat gaji (0.85), sikap terhadap kepatuhan zakat gaji (0.85), norma subjektif (0.96), dan kawalan gelagat ditanggap (0.90). Pemeriksaan ke atas matrik data pula menunjukkan bahawa penggunaan analisis faktor adalah bersesuaian di mana nilai KMO melebihi 0.70 (Hair et al., 1988). Nilai KMO bagi niat gelagat kepatuhan zakat gaji (0.85), sikap terhadap kepatuhan zakat gaji (0.81), norma subjektif (0.92), dan kawalan gelagat ditanggap (0.87). Justeru itu, instrumen yang digunakan bagi mengukur data ketiga-tiga angkubah tersebut berada pada posisi yang cukup baik.

Responden bagi kajian ini terdiri daripada 48.8\% lelaki dan 51.6\% perempuan dan umur purata mereka adalah 40.5 tahun. Sebanyak 69\% datangnya daripada kalangan sektor kerajaan dan selebihnya 31\% daripada kalangan sektor swasta.

Jadual 1 memaparkan keputusan analisis faktor (analisis komponen prinsipal) bagi pemboleh ubah sikap. Sebanyak enam komponen terbentuk yang mempunyai nilai eigenvalue melebihi 1. Jumlah varian yang mewakili enam komponen tersebut adalah 58\% dan dikira memuaskan (Hair et al., 1988). Peratus varians yang tertinggi bagi pemboleh ubah sikap ini datangnya daripada komponen satu, iaitu 23.5\%. Ini diikuti komponen dua hingga enam masing-masing $13.3 \%$, $6.3 \%, 5.4 \%, 5.1 \%$ dan $4.5 \%$. Setiap komponen akan diletakkan nama bagi mewakili dimensi yang berkaitan dengan sikap ke atas zakat gaji. Setiap 
nama yang dicadangkan adalah sikap secara am, sikap was-was, sikap positif, sikap perkara teknikal, sikap bersyarat, dan sikap tanpa syarat. Bagi item-item dalam komponen sikap secara am beban faktor berjulat antara 0.51 hingga 0.65 . Komponen sikap was-was berbeban faktor antara 0.47 hingga 0.72 . Item-item komponen sikap positif pula berkisar antara 0.50 hingga 0.85 . Beban faktor item-item dalam komponen sikap bersyarat berada di antara 0.61 hingga 0.67. Item-item dalam sikap tanpa syarat berjulat antara 0.51 hingga 0.62 . Akhir sekali, item-item dalam komponen sikap perkara teknikal membawa beban faktor antara 0.78 dan 0.86 .

Jadual 1: Matriks Komponen Diputar bagi Sikap (n=250)

\begin{tabular}{|c|c|c|c|c|c|c|c|}
\hline & \multicolumn{2}{|c|}{ Nombor } & \multicolumn{4}{|c|}{ Komponen(Beban Faktor) } & \multirow[b]{2}{*}{6} \\
\hline & Item & 1 & 2 & 3 & 4 & 5 & \\
\hline \multicolumn{8}{|l|}{$\overline{\text { Sikap secara am (6 item) }}$} \\
\hline Masuk dalam sukatan pelajaran & 20 & .651 & & & & & \\
\hline Kenakan tindakan & 8 & .642 & & & & & \\
\hline Beritahu orang supaya bayar & 11 & .617 & & & & & \\
\hline Hutang pada tuhan jika tidak bayar & 22 & .567 & & & & & \\
\hline Patut telah lama dilaksanakan & 18 & .552 & & & & & \\
\hline Tinggal salah satu rukun & 19 & .509 & & & & & \\
\hline \multicolumn{8}{|l|}{ Sikap was-was (4 item) } \\
\hline \multicolumn{8}{|l|}{ Mengelirukan-ada negeri } \\
\hline belum wajib & 15 & & .723 & & & & \\
\hline Kaji semula & 14 & & .701 & & & & \\
\hline Tanya ustaz dulu & 17 & & .482 & & & & \\
\hline Ulamak tidak sepakat & 10 & & .466 & & & & \\
\hline \multicolumn{8}{|l|}{ Sikap positif (4 item) } \\
\hline Mesti bayar & 1 & & & .850 & & & \\
\hline Zakat wajib bila cukup syarat & 3 & & & .813 & & & \\
\hline Gembira bayar & 2 & & & .714 & & & \\
\hline Membersihkan pendapatan & 6 & & & .503 & & & \\
\hline \multicolumn{8}{|l|}{ Sikap Bersyarat (3 item) } \\
\hline Tunggu sistem yang baik & 23 & & & & .667 & & \\
\hline Susah dilaksanakan & 13 & & & & .652 & & \\
\hline Seragam hukum disemua negeri & 16 & & & & -.605 & & \\
\hline \multicolumn{8}{|l|}{ Sikap Tanpa Syarat (5 item) } \\
\hline Sesuai dilaksanakan & 12 & & & & & .616 & \\
\hline Tetap bayar walaupun tak jelas & 7 & & & & & .564 & \\
\hline Baik bayar zakat simpanan & 21 & & & & & .528 & \\
\hline Kiraan mudah & 24 & & & & & .545 & \\
\hline Redha potong gaji & 9 & & & & & .514 & \\
\hline \multicolumn{8}{|l|}{ Sikap perkara teknikal (2 item) } \\
\hline Kiraan macam cukai & 4 & & & & & & .856 \\
\hline Taksiran keliru & 5 & & & & & & .780 \\
\hline
\end{tabular}

Kaedah Cabutan: Analisis Komponen Utama. Kaedah Pusingan: Varimax dengan Kaiser Normilization.

Pusingan dijuruskan dalam 10 ulangan. 
Jadual 2 pula memaparkan keputusan analisis faktor (analisis komponen prinsipal) bagi pemboleh ubah norma subjektif. Terdapat tiga komponen mempunyai nilai eigenvalue melebihi 1 . Jumlah varian yang mewakili bagi ketiga-tiga komponen tersebut adalah $80 \%$. Nama-nama yang dicadangkan adalah kepercayaan normatif prima, kepercayaan normatif luaran, dan kepercayaan normatif pasangan. Peratus yang paling tinggi datangnya daripada komponen kepercayaan normatif prima, iaitu $62.2 \%$ dan diikuti komponen kepercayaan luaran dan kepercayaan normatif pasangan yang mana peratusan masing-masing adalah 10.9\% dan $6.7 \%$. Setiap komponen diberikan nama bagi mewakili dimensi yang berkaitan dengan norma subjektif terhadap zakat gaji. Komponen kepercayaan normatif prima mempunyai beban faktor selepas diputar berkisar antara 0.65 hingga 0.83 . Kepercayaan normatif luaran dan kepercayaan normatif pasangan masing-masing mempunyai beban faktor 0.61 hingga 0.87 dan 0.71 hingga 0.77 .

Jadual 2: Matriks Komponen Diputar bagi Norma Subjektif $(\mathrm{n}=250)$

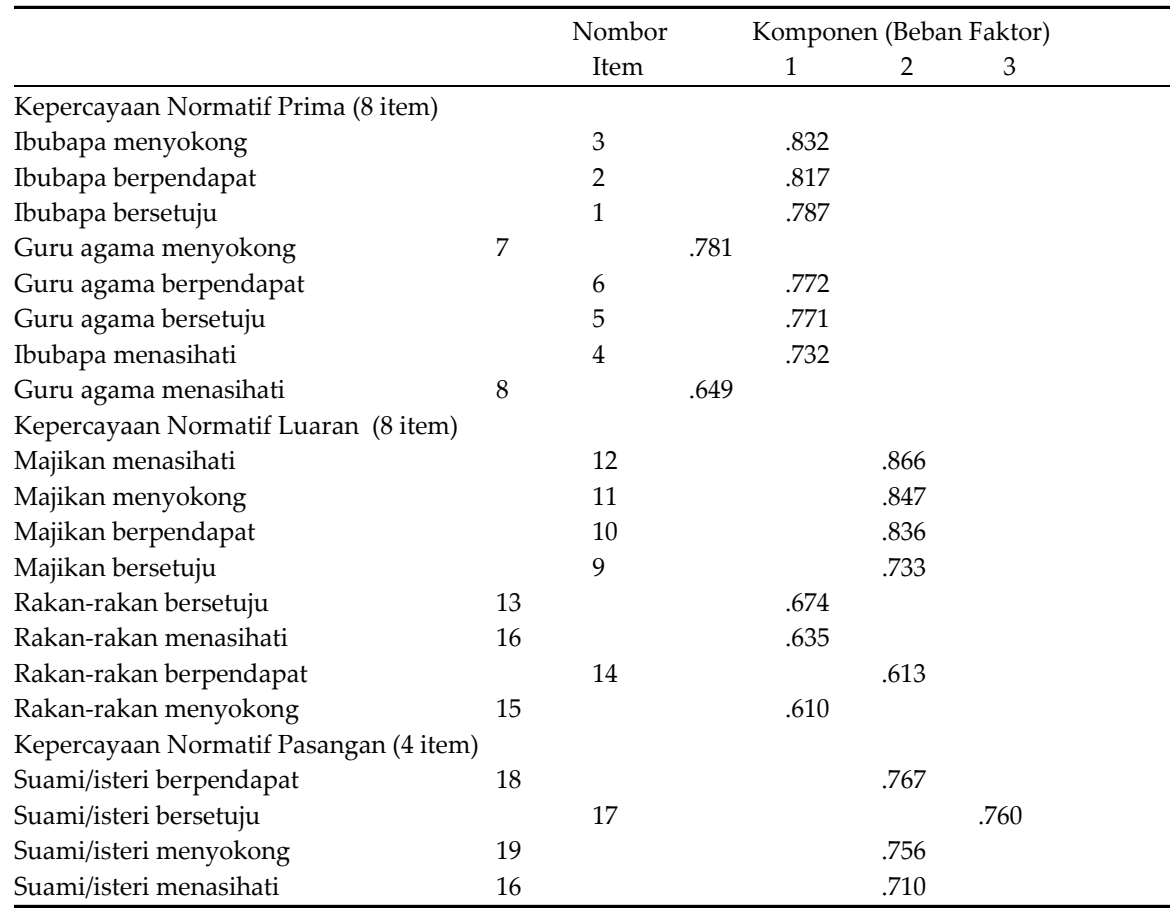

Kaedah Cabutan: Analisis Komponen Utama. Kaedah Pusingan: Varimax dengan Kaiser Normilization. Pusingan dijuruskan dalam 6 ulangan. 
Jadual 3 menunjukkan keputusan analisis faktor (analisis komponen prinsipal) bagi pemboleh ubah kawalan gelagat ditanggap. Hanya satu komponen sahaja terbentuk di bawah pemboleh ubah ini. Jumlah varian yang mewakili komponen ini adalah $72 \%$. Kelima-lima item berbeban faktor melebihi 0.60 dan julat antara item berada pada kedudukan antara 0.70 hingga 0.90 . Jadual 4 pula memaparkan keputusan analisis faktor (analisis komponen prinsipal) bagi pemboleh ubah niat gelagat. Pemboleh ubah ini dihuni oleh satu komponen selepas melalui prosedur analisis faktor. Peratus varian diterang adalah sebanyak 71\%. Lima item yang mengukur pemboleh ubah ini berjulat antara 0.61 hingga 0.95 .

Jadual 3: Matriks Komponen Diputar bagi Kawalan Gelagat Ditanggap $(n=250)$

\begin{tabular}{lcc}
\hline & $\begin{array}{l}\text { Nombor } \\
\text { Item }\end{array}$ & Komponen (Beban Faktor) \\
\hline $\begin{array}{l}\text { Saya boleh laksana tugas dengan berkesan } \\
\text { termasuk bayar zakat }\end{array}$ & 2 & .900 \\
$\begin{array}{l}\text { Saya mampu untuk bayar zakat walaupun } \\
\text { hadapi banyak cabaran }\end{array}$ & 1 & .874 \\
$\begin{array}{l}\text { Walaupun hadapi masalah kewangan, } \\
\text { saya mampu bayar zakat setiap tahun }\end{array}$ & 3 & .866 \\
$\begin{array}{l}\text { Saya mampu bayar zakat kerana saya } \\
\text { telah bayar cukai sebelum ini }\end{array}$ & 5 & .828 \\
$\begin{array}{l}\text { Saya mampu untuk capai semua matlamat } \\
\text { termasuk bayar zakat }\end{array}$ & 4 & .794 \\
\hline $\begin{array}{l}\text { Kaedah Cabutan: Analisis Komponen Utama. Kaedah Pusingan } \\
\text { Mala }\end{array}$ & &
\end{tabular}

Jadual 4: Matriks Komponen Diputar bagi Niat Gelagat Kepatuhan Zakat Gaji (n=250)

\begin{tabular}{lcc}
\hline & $\begin{array}{c}\text { Nombor } \\
\text { Item }\end{array}$ & Komponen (Beban Faktor) \\
\hline $\begin{array}{l}\text { Saya akan bayar zakat gaji } \\
\text { Saya akan bayar zakat gaji tiap-tiap tahun }\end{array}$ & 1 & .955 \\
$\begin{array}{l}\text { Saya akan tambah zakat gaji apabila } \\
\text { pendapatan saya bertambah }\end{array}$ & 2 & .943 \\
$\begin{array}{l}\text { Saya akan hubungi pejabat zakat untuk } \\
\text { bayar zakat gaji }\end{array}$ & 3 & .925 \\
$\begin{array}{l}\text { Saya akan dapatkan borang potongan gaji } \\
\text { untuk bayar zakat gaji }\end{array}$ & 5 & .736 \\
\hline
\end{tabular}

Kaedah Cabutan: Analisis Komponen Utama. Kaedah Pusingan 
Jadual 5 memaparkan keputusan analisis berganda bagi pemboleh ubah sikap dan norma subjektif terhadap niat gelagat kepatuhan zakat gaji. Sejumlah 56\% varians (Adjusted R-square) bagi niat diterang oleh pemboleh ubah sikap (mewakili enam komponen) dan norma subjektif (mewakili tiga komponen) dan kawalan gelagat ditanggap. Jadual 5 tersebut juga menunjukkan pemboleh ubah bebas berkenaan berhubungan secara signifikan dengan niat gelagat zakat gaji. Pemboleh ubah bebas bagi sikap yang terdiri daripada enam komponen mempunyai tiga komponen berkedudukan signifikan dan berkait secara positif dengan niat gelagat kepatuhan zakat gaji. Komponen-komponen tersebut adalah sikap secara am, sikap positif, dan sikap bersyarat. Tiga lagi komponen dalam pemboleh ubah sikap didapati tidak signifikan. Kesemua pemboleh ubah norma subjektif yang diwakili tiga komponen menunjukkan kedudukan yang signifikan dan mempunyai perkaitan yang positif dengan niat gelagat kepatuhan zakat gaji. Komponen kumpulan rujukan normatif luaran berkait secara positif dan signifikan pada tahap marginal $(\mathrm{p}<0.10)$. Akhir sekali pemboleh ubah kawalan gelagat ditanggap turut memberi kesan ke atas niat gelagat kepatuhan zakat gaji. Pemboleh ubah kumpulan rujukan normatif prima memberi kesan yang paling kuat berbanding dengan lain-lain komponen iaitu beta standardnya adalah 0.310 . Ini diikuti di tempat kedua oleh komponen kawalan gelagat ditanggap dan seterusnya.

Berdasarkan analisis di Jadual 5, model regresi berganda tersebut boleh diterangkan seperti berikut:

$N G K=-0.009 \alpha+0.110 C_{11}+0.158 C_{12}+0.164 C_{13}+0.128 C_{14}+0.192 C_{15}+0.08 C_{16}$ $+0.310 D_{21}+0.090 D_{22}+0.157 D_{23}+0.218 E_{33}$

di mana:

NGK adalah niat gelagat kepatuhan zakat gaji

$\mathrm{C}_{11}$ adalah sikap secara am

$\mathrm{C}_{12}$ adalah sikap was-was

$\mathrm{C}_{13} \quad$ adalah sikap positif

$\mathrm{C}_{14} \quad$ adalah sikap bersyarat

$\mathrm{C}_{15}$ adalah sikap tanpa syarat

$\mathrm{C}_{16} \quad$ adalah sikap perkara teknikal

$\mathrm{D}_{21} \quad$ adalah kepercayaan normatif prima

$\mathrm{D}_{22} \quad$ adalah kepercayaan normatif luaran

$\mathrm{D}_{23} \quad$ adalah kepercayaan normatif pasangan

$\mathrm{E}_{33} \quad$ adalah komponen kawalan gelagat ditanggap 
Jadual 5: Analisis Regresi Berganda Niat Gelagat Kepatuhan Zakat Gaji $(\mathrm{n}=250)$

Koeffisien ${ }^{\mathrm{a}}$

\begin{tabular}{|c|c|c|c|c|c|}
\hline & \multicolumn{5}{|c|}{ Unstandardized Standardized } \\
\hline & \multicolumn{2}{|c|}{ Coefficients } & \multicolumn{3}{|l|}{ Coefficients } \\
\hline Model & B & Std. Error & Beta & $t$ & Sig \\
\hline $\begin{array}{l}\text { (Constant) } \\
\text { Faktor skor }\end{array}$ & -.009 & .047 & & -.200 & .842 \\
\hline $\begin{array}{l}\text { komponen sikap } 1 \\
\text { Faktor skor }\end{array}$ & .115 & .058 & .110 & 2.003 & $.047^{* *}$ \\
\hline $\begin{array}{l}\text { komponen sikap } 2 \\
\text { Faktor skor }\end{array}$ & .058 & .048 & .058 & 1.197 & .233 \\
\hline $\begin{array}{l}\text { komponen sikap } 3 \\
\text { Faktor skor }\end{array}$ & .172 & .055 & .164 & 3.096 & $.002^{*}$ \\
\hline $\begin{array}{l}\text { komponen sikap } 4 \\
\text { Faktor skor }\end{array}$ & .130 & .054 & .128 & 2.412 & $.017^{* *}$ \\
\hline $\begin{array}{l}\text { komponen sikap } 5 \\
\text { Faktor skor }\end{array}$ & .189 & .050 & .192 & 3.795 & $.000^{*}$ \\
\hline $\begin{array}{l}\text { komponen sikap } 6 \\
\text { Faktor skor }\end{array}$ & .009 & .048 & .008 & .178 & .859 \\
\hline $\begin{array}{l}\text { komponen norma subjektif } 1 \\
\text { Faktor skor }\end{array}$ & .320 & .060 & .310 & 5.326 & $.000^{*}$ \\
\hline $\begin{array}{l}\text { komponen norma subjektif } 2 \\
\text { Faktor skor }\end{array}$ & .092 & .053 & .090 & 1.716 & $.088^{* * *}$ \\
\hline $\begin{array}{l}\text { komponen norma subjektif } 3 \\
\text { Faktor skor }\end{array}$ & .169 & .059 & .157 & 2.860 & $.005^{*}$ \\
\hline $\begin{array}{l}\text { Komponen kawalan gelagat } \\
\text { ditanggap }\end{array}$ & .220 & .070 & .218 & 3.151 & $.002^{*}$ \\
\hline
\end{tabular}

a. Peramal: (Konstan), Faktor skor komponen sikap 1, Faktor skor komponen sikap 2, Faktor skor komponen sikap 3, Faktor skor komponen sikap 4, Faktor skor komponen sikap 5, Faktor skor komponen sikap 6, Faktor skor komponen norma subjektif 1, Faktor skor komponen norma subjektif 2, Faktor skor komponen norma subjektif 3, Faktor skor komponen kawalan gelagat ditanggap.

b. $\quad$ S Square $=.585 ;$ Adjusted $R$ Square $=.563 ;$ F statistics $=27.157 ;$ Sig $=0.000$.

c. $\quad * * * / * * *=p<0.01 / p<0.05 / p<0.10$ 


\section{PERBINCANGAN}

Keputusan kajian menunjukkan bahawa pemboleh ubah sikap dan norma subjektif terdiri daripada beberapa komponen. Ini mengesahkan teori latitud sikap yang dicadangkan oleh Sherif dan Hovland (1961) dan teori pembelajaran sosial oleh Bandura (1977). Bagi pemboleh ubah sikap, Sherif dan Hovland (1961) memperkenalkan sikap berkedudukan secara berselang yang terdiri daripada komponen kognitif dan afektif yang saling bertaut antara satu sama lain. Mueller (1986) juga menekankan sikap yang kompleks mungkin mengandungi dua atau lebih komponen. Kajian dalam persekitaran zakat gaji ini turut menyokong saranan yang dibuat mereka. Dapatan kajian menunjukkan bahawa sikap dalam kalangan anggota masyarakat Muslim turut berkedudukan secara berselang. Antara selang tersebut termasuk sikap secara am, sikap was-was, sikap positif, sikap perkara teknikal, sikap bersyarat, dan sikap tanpa syarat. Setiap individu mempunyai penilaian yang berbeza berdasarkan kepercayaan masing-masing. Bentuk atau komponen sikap ini yang berperanan dalam diri seseorang bagi membuat keputusan menunaikan tanggungjawab membayar zakat gaji. Dapatan seperti ini konsisten dengan penemuan yang dibuat oleh beberapa penyelidik sebelum ini dalam persekitaran zakat dan cukai (Bobek, 1997; Eriksen \& Fallan, 1996; Hanno \& Violette, 1996; Kamil, 2002; Kamil \& Ahmad Mahzan, 2001; Zainol \& Kamil, 2007).

Berdasarkan kajian ini, tiga komponen sikap iaitu sikap secara am, sikap postif, dan sikap bersyarat berkaitan secara positif dan signifikan terhadap niat gelagat kepatuhan zakat pendapatan gaji. Dapatan ini menyokong teori gelagat terancang yang bangunkan oleh Ajzen yang menekankan sikap merupakan elemen yang penting dalam mempengaruhi niat gelagat individu. Penemuan daripada kajian jelas mengambarkan sikap yang hanya bersandarkan kepada penerimaan secara am sahaja tidak memadai bagi menarik anggota masyarakat Muslim bagi membayar zakat gaji. Pendekatan yang lebih konklusif dan berkesan haruslah dibuat dalam usaha menarik pekerja Muslim agar lebih bersikap positif terhadap zakat pendapatan gaji. Penerimaan sikap secara was-was hendaklah diberi tumpuan oleh pihak yang berwajib supaya ianya dapat menyakinkan para pekerja Muslim bersikap lebih positif ke atas zakat penggajian ini. Usaha yang bersungguh-sungguh seperti memberi maklumat melalui saluran media elektronik, media cetak dan sebagainya perlulah ditingkatkan secara berterusan. Ini kerana isu berkaitan dengan agama seperti zakat jenis ini masih lagi diperdebatkan dan memerlukan langkah yang lebih proaktif dalam usaha menyedarkan mereka yang layak membayar zakat gaji. 
Sikap am dan sikap positif yang ditunjukkan sesetengah pekerja Muslim ini memaparkan mereka lebih bersifat konservertif dalam hal keagamaan seperti menerima fatwa wajib zakat gaji. Namun demikian, usaha perlulah dipertingkatkan lagi agar sikap penerimaan secara waswas beralih kepada sikap positif. Pendekatan melalui penguatkuasaan haruslah disemak dan kualiti perkhidmatan hendaklah dibuat penambahbaikan kerana ianya merupakan pendorong kepada gelagat kepatuhan zakat gaji (Kamil \& Ahmad Mahzan, 2001). Lain-lain komponen sikap seperti sikap berkaitan dengan perkara teknikal, sikap was-was, dan sikap bersyarat yang tertanam dalam sesetengah individu Muslim perlu juga diberi perhatian oleh pihak berkuasa zakat dalam memastikan mereka lebih berpandangan positif tentang zakat gaji ini.

Kedudukan pemboleh ubah norma subjektif berada dalam keadaan yang serupa dengan pemboleh ubah sikap. Keputusan kajian menunjukkan norma subjektif atau kumpulan rujukan masyarakat Muslim ke atas zakat gaji datang daripada pelbagai kumpulan rujukan yang berbeza. Sehubungan itu, dapatan yang diperolehi daripada kajian ini turut mengesahkan bahawa individu Muslim juga tidak terlepas daripada tekanan sosial atau melalui pemerhatian oleh kumpulan orang tertentu dalam niat berzakat. Kumpulan rujukan tersebut terdiri daripada kepercayaan normatif prima, kepercayaan normatif luaran, dan kepercayaan normatif pasangan. Oleh itu, dapatan kajian ini selari dengan saranan yang dibuat oleh Bandura (1977) dan Ajzen dan Fishbein (1980) di mana kumpulan tertentu menjadi rujukan bagi seseorang dalam melaksanakan sesuatu gelagat. Kedudukan yang signifikan bagi ketiga-tiga kumpulan rujukan ini menggambarkan bahawa individu Muslim cenderung mengambil pandangan atau pendapat Muslimin yang lain dalam hal yang berkaitan dengan agama seperti zakat. Di samping peranan ibu bapa, pasangan, dan guru agama, pendapat rakan-rakan dan juga majikan turut menyumbang dalam membentuk kepercayaan normatif ini. Ini kerana pandangan daripada kumpulan rujukan tertentu dapat memotivasikan mereka dalam menyesuaikan dengan norma-norma kumpulan tersebut (Bobek, 1997). Penemuan kajian ini selari dengan beberapa kajian terdahulu seperti $\mathrm{Chu}$ dan Wu (2004) dan Taylor dan Todd (1995) di mana pemboleh ubah norma subjektif boleh dibahagikan kepada komponen kepercayaan normatif prima (seperti keluarga) dan kepercayaan normatif sekunder (seperti penyelia dan rakan-rakan). Dapatan kajian mereka menyokong bahawa kepercayaan normatif ini berhubungan secara positif dan signifikan dengan niat gelagat. 
Pemboleh ubah kawalan gelagat ditanggap juga turut memainkan peranan penting dalam mempengaruhi niat gelagat kepatuhan zakat gaji. Menurut Ajzen (1991), pemboleh ubah ini dikaitkan dengan keupayaan atau kemampuan yang ada pada seseorang itu bagi melaksanakan sesuatu gelagat. Dalam kajian ini jelas membuktikan kemampuan yang ada pada individu Muslim seperti kedudukan kewangan, pengetahuan dan kefahaman tentang zakat, dan sebagainya merupakan faktor yang berperanan penting dalam mempengaruhi niat individu dalam menunaikan zakat. Kedudukan ini juga selari dengan penemuan kajian yang lepas (Chu \& Wu, 2004; Elliott et al., 2004; Fang \& Shih, 2004; Ingram et al., 2000; Taylor \& Todd, 1995). Sehubungan itu, pihak pejabat zakat perlulah memainkan peranan lebih aktif demi meningkatkan kemampuan individu Muslim dalam menunaikan zakat gaji ini. Dicadangkan pihak pejabat zakat dapat melantik ejen atau amil di setiap organisasi supaya potongan gaji bulanan seperti mana yang dilakukan oleh pihak Lembaga Hasil Dalam Negeri. Ini supaya mereka tidak dibebani dengan masalah kewangan jika membayar zakat secara sekaligus.

\section{RUMUSAN}

Dapatan kajian ini memaparkan bahawa terdapat pelbagai komponen dalam pemboleh ubah sikap dan norma subjektif. Kedua-dua pemboleh ubah ini serta pemboleh ubah kawalan gelagat ditanggap dapat mendorong niat gelagat kepatuhan zakat gaji. Dengan menggunakan pendekatan analisis faktor, pemboleh ubah sikap dan norma subjektif dapat dirungkaikan kepada beberapa komponen seperti yang dibincangkan. Sehubungan itu, ianya dapat memberi maklumat yang berguna kepada institusi zakat tentang sikap dan norma subjektif para pekerja Muslim. Pihak berkuasa zakat perlulah melihat sikap Muslimin dengan lebih komprehensif dan tidak hanya memfokus tentang sesuatu perkara sahaja. Sebarang langkah yang diatur demi memastikan kutipan zakat dapat dipertingkatkan haruslah mengambil kira komponen sikap tersebut. Malah, kumpulan rujukan perlu juga diberi keutamaan di mana pendekatan yang lebih strategik perlu dipertimbangkan seperti menggunakan saluran promosi di pejabat dan melalui media massa haruslah ditingkatkan agar semua golongan dapat disasarkan. Di samping itu, pemboleh ubah kawalan gelagat ditanggap juga menyumbang kepada niat gelagat kepatuhan zakat gaji. Justeru, sebarang usaha untuk meningkatkan niat gelagat seterusnya 
melaksanakan gelagat kepatuhan zakat pendapatan gaji dalam kalangan Muslimin haruslah mengambil kira faktor sikap, norma subjektif, dan kawalan gelagat ditanggap ini.

Responden kajian ini hanya tertumpu dalam kalangan pekerja Muslim di sektor kerajaan dan swasta di negeri Kedah. Dengan itu, darjah sandaran am (generalization) dapatan kajian ini adalah terhad. Pada masa hadapan, penyelidik haruslah mengambil kira para pekerja Muslim yang meliputi setiap negeri di Malaysia.

\section{RUJUKAN}

50,000 pekerja Islam dikesan layak bayar zakat. (2000, Sept. 15). Utusan Malaysia, Utara, hlm.25.

Ajzen, I. (1985). From intentions to actions: A theory of planned behavior. In J. Kuhi \& J. Beckmann (Eds.), Action-control: From cognition to behavior (pp.11-39). Heidelberg: Springer.

Ajzen, I. (1991). The theory of planned behavior. Organizational Behavior and Human Decision Processes, 50, 179-211.

Ajzen, I., \& Driver, B.L. (1992). Application of the theory of planned behavior to leisure choice. Journal of Leisure Research, 24(3), 207224.

Ajzen, I., \& Fishbein, M. (1980). Understanding attitudes and predicting social behavior, Englewood Cliffs, NJ: Prentice-Hall.

Ajzen, I., \& Madden, T.J. (1986). Prediction of goal directed behavior: Attitudes, intentions, and perceived behavioural control. Journal of Experimental Social Psychology, 22, 453-474.

Aronson, E., \& Pratkanis, A. (1993). The international library of critical writings in psychology: Social psychology 2. Hants, England: Edward Elgar Publishing.

Aronson, E., Wilson, T.D., \& Akert, R.M. (1999). Social psychology (3rd ed.). New York: Longman.

Bandura, A. (1977). Social learning theory. Englewood Cliffs: Prentice Hall.

Bobek, D.D. (1997). Tax fairness: How do individuals judges fairness and what effects does it have on their behavior. Ph.D. Dissertation, University of Florida, Gainesville.

Bobek, D.D., \& Hatfield, R.C. (2003). An investigation of the theory of planned behavior and the role of moral obligation in tax compliance. Behavioral Research in Accounting, 15, 13-38.

$\mathrm{Chu}$, P.Y., \& Wu, T.Z. (2004). Factors influencing tax-payer information usage behavior: Test of an integrated model. The Eighth PacificAsia Conference on Information Systems, Shanghai, China. 
Churchill, G.A. Jr. (1979). A paradigm for developing better measures of marketing constructs. Journal of Marketing Research, 16(1), 64-73.

Coakes, S.J., \& Steed, L.G. (1999). SPSS analysis without anguish. Brisbane, Australia: John Wiley \& Sons.

Elliott, M.A, Armitage, C.J., \& Baughan, C.J. (2003). Driver's compliance with speed limits: An application of the theory of planned behavior. Journal of Applied Psychology, 88(5), 964-972.

Eriksen, K., \& Fallan, L. (1996). Tax knowledge and attitudes towards taxation: A report on a quasi-experiment. Journal of Economic Psychology, 17(3), 387-402.

Fang, K., \& Shih, Y. (2004). The use of a decomposed theory of planned behavior to study internet banking in Taiwan. Internet Research, 14(3), 213-223.

Hair, J.F., Anderson, R.E., Tatham, R.L., \& Black, W.C. (1998). Multivariate data analysis. New Jersey: Prentice Hall.

Hanno, D., \& Violette, G.R. (1996). An analysis of moral and social influences on taxpayer behavior. Behavioral Research in Accounting, 8.

Holloway, A., \& Watson, H.E. (2002). Role of self-efficacy and behavior change. International Journal of Nursing Practice, 8, 106-115.

Ingram, K.L., Cope, J.G., Harju, B.L., \& Wuensch, K.L. (2000). Applying to graduate school: A test of the theory of planned behavior. Journal of Social Behavior and Personality, 15(2), 215-226.

Jawatankuasa Syariah Negeri Perlis. (1996). Fatwa Negeri Perlis, Kangar: Majlis Agama Islam dan Adat Istiadat Negeri Perlis.

Kamil. (2002). Gelagat kepatuhan zakat gaji di kalangan kakitangan awam. Tesis Ph.D tidak diterbitkan, Universiti Utara Malaysia, Malaysia.

Kamil \& Ahmad Mahdzan. (2001). Attitude towards zakah on employment income: Comparing outcomes between single score and multidimensional scores. Malaysian Management Journal, 5(1\&2), 47-63.

Kamil, Chek Derashid \& Engku Ismail. (1997, Nov.). Zakat penggajian: Suatu tinjauan terhadap pengetahuan dan amalan Muslimin negeri Perlis. Kertas kerja dibentangkan di Seminar Penyelidikan Universiti Utara Malaysia, Sintok, Kedah.

Lau, A.S.M. (2002). Strategies to motivate brokers adopting on-line trading in Hong Kong financial market. Review of Pacific Basin Financial Markets and Policies, 5(4), 471-489.

Mohd Yusof Abas. (1981). 40 Hadith pilihan. Kuala Lumpur: Yayasan Dakwah Islamiah Malaysia.

Mueller, D.J. (1986). Measuring social attitudes, teachers college. Columbia University, New York.

54 IJMS 16 (1), 31-55 (2009) 
Mujaini Tarimin. (1995). Zakat penggajian: Satu penilaian terbaru di Malaysia. Tesis Phd, Universiti Malaya, Malaysia.

Nunnally, J.C. (1978). Psychometric theory (2nd ed.). New York: McGrawHill.

Notani, A.S. (1998). Moderators of perceived behavioral control's predictiveness in the theory of planned behavior: A Meta-Analysis. Journal of Consumer Psychology, 7(3), 247-271.

Oliver, R.L., \& Bearden, W.O. (1985). Crossover effects in the theory of reasoned action: A moderating influence attempt. Journal of Consumer Research, 12, 324-340.

Oskamp, S. (1991). Attitude and opinions (2nd ed.). Englewood Cliffs Prentice Hall.

Rhodes, R.E., \& Courneya, K.S. (2003). Investigating multiples components of attitude, subjective norm, and perceived control: An examination of the theory of planned behavior in the exercise domain. British Journal of Social Psychology, 42, 129-146.

Sherif, M., \& Hovland, C.I. (1961). Social judgement: Assimilation and contrast effects in communication and attitude change. New Haven: Yale Universiti Press.

Shimp, T.A., \& Kavas, A. (1984). The theory of reasoned action applied to coupon usage. Journal of Consumer Research, 11,795-809.

Silver, D.P. (1995). Tax compliance and taxpayer attitude: Over the last forty years, this country has experienced a taxpayer revolt. National Public Accountant, 40(11), 32-35.

Taylor, S., \& Todd, P. (1995). Decomposition and crossover effects in the theory of planned behavior: A study of consumer adoption intentions. International Journal of Research in Marketing, 12, 137-55.

Trafimow, D., Sheeran, P., Conner, M., \& Finlay, K.A. (2002). Evidence that perceived behavioral control is a multidimensional construct: Perceived control and perceived difficulty. British Journal of Social Psychological, 41, 101-121.

Zakat kukuhkan Nusantara. (2006, Mac16). Utusan Malaysia, hlm. 11.

Zainol \& Kamil. (2007). The role of attitude and subjective norm on intention to comply zakah on employment income. IkaZ International Journal of Zakat, 1(1). 